SARA NAKHJIRKAN, M.Sc. ${ }^{1}$

Corresponding author

E-mail: nakhjirkan@yahoo.com

FARIMAH MOKHATAB RAFIEI, Ph.D. ${ }^{2}$

E-mail: f.mokhatab@modares.ac.ir

${ }^{1}$ Department of Industrial and Systems Engineering

Isfahan University of Technology, Isfahan, Iran

2 School of Industrial and Systems Engineering

Tarbiat Modares University, Tehran, Iran
Transport Logistics

Preliminary Communication

Submitted: 8 June 2016

Accepted: 4 May 2017

\title{
AN INTEGRATED MULTI-ECHELON SUPPLY CHAIN NETWORK DESIGN CONSIDERING STOCHASTIC DEMAND: A GENETIC ALGORITHM BASED SOLUTION
}

\begin{abstract}
The growing trend of natural resources consumption has caused irreparable losses to the environment. The scientists believe that if environmental degradation continues at its current pace, the prospect of human life will be shrouded in mystery. One of the most effective ways to deal with the environmental adverse effects is by implementing green supply chains. In this study a multilevel mathematical model including supply, production, distribution and customer levels has been presented for routing-location-inventory in green supply chain. Vehicle routing between distribution centres and customers has been considered in the model. Establishment place of distribution centres among potential places is determined by the model. The distributors use continuous review policy $(r, Q)$ to control the inventory. The proposed model object is to find an optimal supply chain with minimum costs. To validate the proposed model and measure its compliance with real world problems, GAMS IDE/ Cplex has been used. In order to measure the efficiency of the proposed model in large scale problems, a genetic algorithm has been used. The results confirm the efficiency of the proposed model as a practical tool for decision makers to solve location-inventory-routing problems in green supply chain. The proposed GA could reduce the solving time by $85 \%$ while reaching on the average $97 \%$ of optimal solution compared with exact method.
\end{abstract}

\section{KEY WORDS}

supply chain network; stochastic mathematical programming; location-inventory-routing problem; Genetic Algorithm;

\section{INTRODUCTION}

Intensifying global competition in an environment that is constantly changing has increased the need for an appropriate response of organizations and emphasizes on their flexibility to uncertain external environment. Today's organizations at the national and international arena require suitable models such as supply chain management to achieve competitive advantage and expectations of customers to reach their proper position and remain on it.

By reviewing the literature, it is obvious that the decisions of this area can be classified into three groups of strategic, tactical and operational ones which cover three types of problems: location allocation problem, inventory control problem and vehicle routing problem. Location allocation problem focuses on finding the optimum location of depots. Inventory control problems focus on delivered quantities and satisfying customers' demand. Vehicle routing problem (VRP) determines optimum routes for vehicles. The existing dependencies among these problems are as follow: VRP depends on inventory control problem and inventory control problem depends on decision made in location allocation problem. In supply chain, the strategy is the recognition of the optimal number of facilities that optimize the logistics. Breaking the problem into sub problems is one of the first moves in supply chain optimization [1].

In order to achieve the optimal solution of supply chain, the researchers have tried to integrate different levels of decisions; therefore, the effects of existing interdependencies are more touchable. So far, most researchers have focused on the integration of two decision levels in the supply chain, in order to get more acceptable results. These studies can be classified into three groups.

The first group is the Location Routing Problems (LRP) that is the combination of vehicle routing problem and facility location problem which are respectively on tactical/operational and strategic decision levels. In most papers each vehicle visits maximum one point at a time, while the vehicles' capacity is not considered [2]; it raises the split delivery problems. In other words, the optimality of routes individually does not provide an optimal supply chain, it also needs to optimize the locations as well. [3, 4]. Prodhon (2011) was 
one of the first researchers who combined the periodic VRP with LRP; to solve the problem he presented a hybrid heuristic method [5]. Among the studies of this group, we can refer to: Prins et al. 2007, Nagy and Salhi (2007), Prodhon and Prins (2014) [4, 6, 7].

The second group is inventory routing problem (IRP). This group of problems is obtained by combining inventory management that is a tactical decision and a vehicle routing problem in operational level [8]. Cha et al. (2008) considered a supply chain with one depot and n-retailer to reach optimal inventory movement throughout entire supply chain and optimal delivery schedule [9]. Other researchers like Solyali (2010), have combined VRP with inventory constraints with considering a finite time horizon [10]. Oppen et al. (2010) analySed an IRP using column generation method. They considered a model with maximum order capacity of 25; their goal was to investigate the existence of exact method solutions for small-size problems. Their results present the effectiveness of heuristic method in small-sized problems in comparison to large-size problems [11]. A. Kleywegt (2002), M. Vidovic (2014), Bertazzi et al. (2002), and Andersson et al. (2010) are some of the researchers who studied IRP $[12,13,8,14]$.

The third group, Inventory Location Problem (ILP), includes strategic decisions (facility location problem) and tactical decisions (inventory management) [15, 16]. By developing a model that connects the strategic to the tactical level Ma and Davidrajuh, , presented in 2005 an iterative structure which considers a central depot, potential wholesaler and retailer [17]. Miranda and Garrido (2009) presented an Inventory Location Problem and studied the effects of not considering inventory. The study shows that in case of changes in demand, the ordering costs will change as well [18].

All of the groups mentioned above, lead the problems to an optimal solution for just two levels; but in order to get the optimal solution for the supply chain, it is necessary to combine all three categories and to obtain an integrated problem. In other words, long-term and short-term decisions should be considered concurrently in a single model. This group of problems is known as Location Inventory Routing Problem (LIRP).

One of the important decisions in LIRP is to determine the basic location of decision making. It is important to know if it happens at a retailer or depot or both. By considering a single-product multi-depot LRP Liu \& Lee (2003) presented a two-phase heuristic method to solve it [19]. Ambrosino and Scutella (2005) presented a linear model in which both routing and location were considered. They utilized a non-linear model to determine the demand [20]. Guerrero et al. (2013) for the first time presented an algorithm to solve multi periodic ILRP with deterministic demand; their algorithm shares the information between decision levels to optimize the problem components. They considered the cost of tactical, operational and strategic decisions, and presented a two-echelon supply chain. This research is a hybrid of heuristic and exact solution method [21]. Javid and Azad (2010) presented a stochastic model to simultaneously make decisions related to location, allocation and inventory at a depot. It also makes the routing decisions. The authors proposed an exact method solution and then presented a heuristic hybrid method which is based on the taboo search and simulated annealing [22]. In 2011, Hiassant and Diabat (2011) studied an LIRP, in which demand is determined. In this research, Mixed Integer Programming (MIP) is used to present a multi-period model [23]. In order to balance strategic, tactical and operational decisions, Guerrero et al. (2013) presented an algorithm for multi-period problem with deterministic demand. A three-layer supply chain of facility, depot and retailer, was considered in this research and an algorithm was developed to solve multi-period LIRP [21]. By eliminating subtour constraints, Lerhlaly et al. developed in 2016 a model that simultaneously optimizes operating costs, risk and routing $\mathrm{CO}_{2}$ emission. They presented an exact bi-objective integer linear model [24]. Mateo et al. (2012) presented a heuristic column generation approach to simultaneously choose depot location and routes. It divides the problem into two problems, a major problem and an auxiliary problem. They proved that the approach is applicable for smallsize problems. The authors considered each depot capacity as infinite and also their stock of products [25]. Zhang et al. (2014) presented a hybrid metaheuristic combined with simulated annealing method to solve LIRP. They considered two-echelon supply chain with multiple depots with a finite capacity. Customers are geographically scattered and have periodic demand. They proved that for large instances, their method is efficient [26]. Bae et al. (2007), de Oliveira et al. (2016) and Mirabi et al. (2010) are some of other researchers in this area [27, 28, 29].

One of the main focuses of today's world is energy efficiency that has inverse relation to fuel consumption. One of the ways to reduce fuel consumption is VRP. Reduction of fuel consumption reduces $\mathrm{CO} 2$ emission and therefore one of the main factors in environmental pollution is fuel consumption [30]. According to the report released in 2008 by the United States Department of Energy (USDOE) there are so many factors that affect fuel consumption. Vehicle speed, mileage and weight of shipment are some of these factors [31]. Based on these factors some of the studies focused on routing in order to reduce fuel consumption in green VRP. Some other studies also consider the capacity and try to maximize vehicles' occupancy In 2016, Qazvini et al. presented a model to Green VRP. They defined two objectives, cost reduction and fuel consumption reduction [32]. From articles in this area we can point out: Ćirović et al. (2014), Qian and Eglese 
(2016), Felipe et al. (2014), Kramer et al. (2015), Koç and Karaoglan (2016) [33, 34, 35, 36, 37].

For integration of various decisions such as supply, distribution, inventory management, production planning, facility locating and vehicle routing processes, we need models that unlike the traditional ones, consider more comprehensive aspects and optimize different decision variables simultaneously. Many studies have optimized subsets of production-inventory-distribution systems. But these models considered only a part of the integrated system based on their needs; and different decision variables, constraints and cost factors have been considered. Besides, none of the available integrated models considered green VRP. In this paper, a MINLP model is proposed for a four-echelon supply chain - including supply, manufacturing, distribution and customer - with uncertain demand. Assumptions such as multi-depot VRP, capacitated VRP, green VRP, capacitated inventory, location, routing, heterogeneous vehicles and stochastic demand, are considered in the model. In the proposed supply chain integrated decisions at three different levels will be considered: strategic level (facility location, locating distribution centres and supplier selection), tactical level (production and inventory levels regarding stochastic demand of customers, vehicle routing), and operational level (on time delivery of customers' demands and coordination in logistic network). The aim of the proposed model is to minimize the supply chain costs while maintaining a specific service level. The objective function is defined as the minimum of total costs. The proposed model has NP-hard complexity and a genetic algorithm is developed to solve largesize problems. The algorithm presented in this paper can find quite accurate (nearly optimal) solutions at considerable less solving time compared to the exact method.

The remainder of this paper is organized as follows: the proposed supply chain network is defined in the next section. Section 2 is devoted to mathematical modelling and linearization procedure. An evolutionary method based on GA is modified to solve the proposed problem in Section 3. In Section 4, numerical results are presented and finally, conclusion is given in the last section

\section{PROBLEM DEFINITION AND PROPOSED MATHEMATICAL MODEL}

The proposed model in this study consists of four levels: supplier, producer, distribution centre and customer. In this supply chain there are $\mathrm{K}$ customers and $P$ products. Each customer's order for each product $p$ is stochastic and has normal distribution with mean $\mu_{p k}$ and variance $\sigma_{p k}^{2}$. The producer buys raw materials and produces products based on customer demand. The producer can purchase raw material $m$ from each of the suppliers. In supplier selection process there are two restrictions: first is that each raw material $m$ should be single-source, that is, it should be purchased only from one supplier; and second, the limited capacity of suppliers should be considered.

The supply chain under study is demand driven. This means that all levels in the supply chain try to fulfil customers' demands. But customers' demands for different products have normal distribution with known mean and variance. In this supply chain the service level is predefined. Hence, each level needs to try to reach specified service level and meet the customers' demand as much as they can. Unfulfilled demands will be backordered.

The delivery time is considered zero at the supplier level. After receiving raw materials and after production of the final products, they will be sent to the distribution centres. Based on some criteria like distance and capacity, the model identifies among potential distribution places which distribution centres should be established. The routing problem identifies which vehicles should be purchased and allocates them to distribution centres; and at the same time it can show how to send final products to customers. $\alpha$ represents the predefined service level.

Distributors use continuous inventory review policy $(r, Q)$. Continuous review policy means that the distributor continuously observes the inventory level. When inventory level reaches amount $r$ (safety stock), it orders the inventory to amount $Q$. The review horizon in this model is infinite. In fact, the model is such that the planning horizon has been considered to be infinite, but the supply chain is planned for one year. After running the model and over a period, the model can be solved again with updated parameters. The following is the assumptions of the proposed model.

Assumptions [32, 38]:

- The amount of raw material ordered to each supplier is a variable dependent on customer demand for each product.

- Customer demand has normal distribution with mean $\mu_{p k}$ and variance $\sigma_{p k}^{2}$ [39].

- Distributors use continuous review policy $(r, Q)$ [40].

- Delivery time at supply level is considered zero.

- The supply chain intended in this research has four levels and involves supply, production, distribution and customer levels. Multi-product and single period are also considered.

- Locating distribution centres is determined by the model.

- The number of available vehicles and their capacity for transport is specified, but the model determines which vehicles should be purchased and used by which distribution centre.

- A green supply chain is considered in this problem which minimizes air pollution produced by vehicles [32]. 
- Transportation time between two nodes by each vehicle in the supply chain is a constant value.

- The possibility of damage to vehicles is not considered in the study.

- Vehicle routing problem is between distributor and customer level.

- Capacity of distribution centres is specified.

Indices

$\begin{array}{lll}i & \text { Supplier } & i=1,2, \ldots l \\ j & \text { Distribution centre } & j=1,2, \ldots J \\ k & \text { Supplier } & k=1,2, \ldots K \\ p & \text { Product } & p=1,2, \ldots P \\ m & \text { Raw material } & m=1,2, \ldots M \\ v & \text { Vehicle } & v=1,2, \ldots V\end{array}$

Parameters

$F_{i} \quad$ - Management cost of supplier $i$

$A M_{m i}$ - Fixed cost of orders to supplier $i$ for purchasing raw material $m$

$C M_{m i}$ - Unit price of raw material $m$ from supplier $i$

max $_{m i}$ - Capacity of supplier $i$ in providing raw material $m$

mini $_{m i}$ - Minimum order of raw material $m$ to supplier $i$

$\mathrm{CO}_{\text {mip }}$ - Coefficient of usage of raw material $m$ pur chased from supplier $i$ to produce product $p$

$H M_{m}$ - Holding cost per unit of raw material $m$

$T_{p j} \quad$ - Transportation cost per unit of product $p$ from producer to distribution centre $j$

$L \quad$ - Lead time in distribution level $L$

$b_{p} \quad$ - Shortage cost per unit of product $p$

$C V_{v} \quad$ - Purchasing cost of vehicle $v$

$\mathrm{CVeh}_{v}$ - Capacity of vehicle $v$

DCus $_{k k^{-}}$- Distance from location of customer $k$ to the location of customer $k$

TCus $_{v \hat{k} k}$ - Time distance from location of customer $k$ to the location of customer by vehicle $v$

$F W S_{j}$ - Establishment cost of distribution centre $j$

$C W_{j}$ - Capacity of distribution centre $j$

$H P_{p} \quad$ - Holding cost per unit of product $p$ in distribution centres

$D_{p k} \quad$ - Demand of customer $k$ for product $p$, $D_{p k} \sim N\left(\mu_{p k} \sigma_{p k}\right)$

$A P_{p j} \quad$ - Fixed cost of ordering product $p$ to distribution centre $j$

$D_{i s_{j k}}$ - Distance of distribution centre $j$ from customer $k$

$t m_{v j k} \quad$ - Time distance from distribution centre $j$ to customer $k$ by vehicle $v$

Fuel $_{v}$ - The rate of fuel consumption per distance unit by vehicle $v$

CFuel - Cost of fuel per unit

$M \sim \infty$ - Big positive number $M$

Variables

$y_{j} \begin{cases}1 & \text { If the distribution centre } j \text { is established } \\ 0 & \text { Otherwise }\end{cases}$ $z_{v} \begin{cases}1 & \text { If vehicle } v \text { is purchased } \\ 0 & \text { Otherwise }\end{cases}$

If vehicle $v$ goes from customer $\hat{k}$ to customer $k$

$\lambda_{v \widehat{k} k}\left\{\begin{array}{l}1 \\ 0\end{array}\right.$ Otherwise

If vehicle $v$ is allocated to distribution centre $j$

$\beta_{v j} \begin{cases}1 & \text { Otherwise } \\ 0 & \end{cases}$

If supplier $i$ is selected for purchasing raw

$x_{m i} \begin{cases}1 & \text { Otherwise } \\ 0 & \end{cases}$

$\mathrm{Q}_{p v k j} \geq 0$ The amount of product $p$ transferred from distribution centre $j$ to customer $k$ by vehicle $v$

$a t_{v k} \geq 0 \quad$ Arrival time of vehicle $v$ at customer $k$

$\operatorname{Min} \sum_{i} F_{i}\left(\min \left\{1, \Sigma_{m} x_{m i}\right\}\right)+\Sigma_{j} \Sigma_{p} A P_{p j} \cdot y_{j} \cdot$

$\cdot\left(\frac{\sum_{k} \mu_{p k}}{\sum_{k} \sum_{j} \sum_{v} Q_{p v k j}}\right)+\sum_{i} \Sigma_{m} \Sigma_{k} \Sigma_{p} C M_{m i} \cdot \mu_{p k} \cdot C O_{m i p} \cdot x_{m i}+$

$+\sum_{j} F W S_{j} \cdot y_{j}+\sum_{j} \sum_{k} \Sigma_{p} \Sigma_{v} Q_{p v k j} \cdot T_{p j}+$

$+\sum_{i} \Sigma_{p} \Sigma_{m} A M_{m i} \cdot\left(\frac{\sum_{k} \mu_{p k} \cdot C O_{m i p}}{\sum_{k} \sum_{j} \Sigma_{v} Q_{p v k j} \cdot C O_{m i p}}\right) \cdot x_{m i}+$

(直 $\sum_{m}\left(\frac{\sum_{p} \sum_{k} \sum_{j} \sum_{i} \sum_{v} Q_{p v k j} \cdot C O_{\text {mip }}}{2}\right) \cdot H_{m}+$

$+\sum_{p}\left(\frac{\sum_{k} \sum_{j} \sum_{v} Q_{p v k j}}{2+z_{\alpha} \sqrt{\sum k^{\sigma^{2}}} p k \sqrt{L}}\right) \cdot H P_{p}+$

$+\sum_{p}\left(\frac{\sum_{k} \mu_{p k}}{\sum_{k} \sum_{j} \sum_{v} Q_{p v k j}}\right) \cdot b_{p} \int_{r_{p}}^{\infty}\left(w_{p}-r_{p}\right) f\left(w_{p}\right) d w_{p}+$

+CFuel $\cdot\left(\sum_{v} \Sigma_{\widehat{k}} \Sigma_{k}\right.$ Fuel $_{v} \cdot \lambda_{v \widehat{k} k} \cdot$ DCus $_{\widehat{k} k}+$

$+\sum_{v} \sum_{j} \sum_{k}$ Fuel $_{v} \cdot\left(\lambda_{v 1 k}+\lambda_{v k 1}\right) \cdot \beta_{v j} \cdot$ Dis $\left._{j k}\right)$

$+\Sigma_{v} z_{v} \cdot C V_{v}$

St:

$\min _{m i} \cdot x_{m i} \leq \sum_{k} \sum_{j} \sum_{p} \Sigma_{v} Q_{p v k j} \cdot C O_{m i p} \leq \max _{m i} X_{m i}$ $\forall m, \forall i$

$\sum_{i} X_{m i}=1 \quad \forall m$

$\sum_{p=1}^{P} \sum_{v=1}^{V} \sum_{k=1}^{K} Q_{p v k j} \leq y_{j} \cdot C W_{j} \quad \forall j$

$\Sigma_{p} \Sigma_{k} Q_{p v k j} \leq \mathrm{CVeh}_{v} \cdot z_{v} \quad \forall v, j$

$\Sigma_{p} \Sigma_{j} \Sigma_{k} Q_{p v k j} \leq M \cdot \Sigma_{j} \beta_{v j} \quad \forall v$

$\Sigma_{j} \beta_{v j} \leq 1 \quad \forall v$

$\sum_{\widehat{k}} \lambda_{v \widehat{k} k} \leq 1 \quad \forall v, k$

$\Sigma_{\widehat{k}} \lambda_{v \widehat{k} k}=\sum_{\widehat{k}} \lambda_{v \widehat{k} k} \quad \forall v, k$

$a t_{v k} \geq \Sigma_{\widehat{k}}\left(a t_{v \widehat{k}}+\right.$ TCUS $\left._{v \widehat{k} k}\right) \cdot \lambda_{v \widehat{k} k} \quad \forall v, k>1$

$a t_{v k} \geq \Sigma_{j} t m_{v j k} \cdot \beta_{v j} \cdot \lambda_{v k 1} \quad \forall v, k$

$\Sigma_{p} \Sigma_{j} Q_{p v k j} \leq M \cdot \Sigma_{\widehat{k}} \lambda_{v \widehat{k} k} \quad \forall v, k$ 
$\sum_{p} \sum_{j} \sum_{k} Q_{p v k j} \leq M \cdot z_{v} \quad \forall v$

$x_{m i} \in\{0,1\}, y_{j} \in\{0,1\}, z_{v} \in\{0,1\}$,

$\lambda_{v \widehat{k} k} \in\{0,1\}, \beta_{v j} \in\{0,1\}, Q_{p v k j} \geq 0, a t_{v k} \geq 0$

The above model is Mixed Integer Non-linear Programming (MINLP). In this model, Objective function 1 is defined as the minimization of costs. These costs include the cost of supply of raw materials, inventory holding cost, products transportation cost, vehicle fuel consumption cost and vehicle purchase costs, shortage costs, ordering costs and costs of establishing distribution centres.

Constraint 2 causes raw material orders to each supplier not to be more or less than the allowed constraints. Also, if a supplier is not selected for material $m$, the item will not be purchased by mistake from that supplier in the final answer. Constraint 3 represents the single source of the supply chain. This means that raw material $m$ should only be purchased from one supplier. Constraint 4 ensures that if a distribution centre is not selected to be established, then no product will be sent to it. Also no product will be delivered from that distribution centre to any customers. Besides, this constraint ensures not to exceed distribution centers' capacity. Constraint 5 states that the amount of goods carried by each vehicle should not exceed its capacity. Based on Constraint 6 the products from distribution centre $j$ to customers will be delivered by vehicle $v$ only if $v$ is assigned to distribution centre $j$. Based on Constraint 7 , if a vehicle is purchased it will be assigned to just one distribution centre. Only one vehicle can visit each customer which is shown in Constraint 8. According to Constraint 9, if a vehicle visited a customer, it should get out of that customer location. Sub-tours elimination and calculating the arrival time to each customer is provided in Constraints 10 and 11 .

If products are sent to customer $k$ by a vehicle, it should be purchased and should visit $k$. This is shown in Constraints 12 and 13, respectively. In Constraint 14 the types of variables used in the model are mentioned.

Location problems and VRP have NP-hard complexity, so solving time increases exponentially as the problem size is enlarged. Thus, it can be concluded that the proposed model which has location and VRP, is NP-hard and can be solved using exact models and commercial solvers only in small-sized problems. Larger sized problems, which are more similar to real world conditions, cannot be solved into optimality in a logical time using exact methods. Hence, a meta-heuristic method has been proposed to find the best possible solutions in shorter solving time. In this respect, a genetic algorithm is utilized. The proposed model has some binary and continuous variables and it has been shown that the genetic algorithm has good performance in discrete problems.

\section{GENETIC ALGORITHM}

The genetic algorithm is inspired by genetics and the Darwin's theory of evolution and is based on the survival of superiors or natural selection. A common application of the genetic algorithm is using it as an optimization function. The model presented in this paper has non-linear phrases and integer variables; hence it will be solved by the genetic algorithm. In GA, each supply chain is an individual constitute of four chromosomes: customer and distribution centre chromosome, vehicle and distribution centre chromosome, customer and vehicle chromosome, supplier selection chromosome. These three chromosomes show which distribution centres will be established, which vehicles should be purchased and their assignment to the established distribution centres and how vehicles will visit customers. To start GA, an initial population will be created and with every iteration better solutions (individuals) will be created through crossover and mutation operators. GA tries to find supply chains which have lower costs. Further in the text it is described how chromosomes and operators will be defined through numerical example.

Three chromosomes are defined for the relationship among distribution centres, customers and vehicles. Suppose there is a problem with three potential distribution centres $(\mathrm{J}=3), 10$ customers $(K=10)$ and 6 vehicles $(\mathrm{V}=6)$.

Customer and distribution centre chromosome: through this chromosome, distribution centres establishment and customer assignment to the established distribution centres will be identified. To generate an initial random solution (chromosome) a random permutation of numbers 1 to 13 will be created. Thirteen is the sum of customers and potential distribution centres $(10+3)$. This chromosome shows customers' assignment to distribution centres. Numbers 1 to 10 are related to customers and 11-13 to distribution centres. In this chromosome all customer numbers before a distribution centre digit will be assigned to that distribution centre.

For the above example, the permutation of $j+k$ is shown in Figure 1:

\begin{tabular}{|l|l|l|l|l|l|l|l|l|l|l|l|l|}
6 & 3 & 7 & 8 & 12 & 5 & 1 & 10 & 2 & 4 & 9 & 11 & 13 \\
\hline
\end{tabular}

Figure 1 - Customer and distribution centre chromosome

According to Figure 1, six customers are assigned to distribution centre 1 , four customers to distribution centre 2, and no customer is assigned to distribution centre 3 . This means distribution centre 3 is not established so no customer will be assigned to it.

Vehicle and distribution centre chromosome: Vehicles purchasing decision and vehicles allocation is shown through this chromosome. Bits values of this chromosome can be changed for any time period 
(day). For this chromosome, permutations of numbers 1 to $v+j$ are used as shown in Figure 2.

\section{\begin{tabular}{|l|l|l|l|l|l|l|l|l|}
\hline 3 & 9 & 5 & 1 & 6 & 7 & 4 & 2 & 8 \\
\hline
\end{tabular}}

Figure 2 - Vehicle and distribution centre chromosome

In the chromosome shown Figure 2, numbers bigger than $\mathrm{V}$ represent the number of the distribution centre. It can be seen that the third vehicle is not assigned to any active distribution centre (it is assigned to the third distribution centre which has not been establishe d). In fact, the third vehicle is not bought based on the above chromosome.

Customer and vehicle chromosome: by this chromosome, routing and sequence of customers visiting are displayed. Bits values of this chromosome can be changed for any time period (day). The following process is used to generate this chromosome.

Do the following process for all active distribution centres:

- Use a variable change as follows. For example, for distribution centre 1, we have (Figure 3):

\begin{tabular}{|l|c|c|c|c|c|c|c|c|c|}
\hline Distribution centre 1 & \multicolumn{5}{|c|}{ Customer } & \multicolumn{4}{|c|}{ Vehicle } \\
\hline Original values & 5 & 1 & 10 & 2 & 4 & 9 & 5 & 1 & 6 \\
\hline Symbolic values & 1 & 2 & 3 & 4 & 5 & 6 & 7 & 8 & 9 \\
\hline
\end{tabular}

Figure 3 - Customer and vehicle chromosome

- At this stage, a permutation of numbers 1 to 9 is created for the first distribution centre as follows.

$$
\begin{array}{|l|l|l|l|l|l|l|l|l|}
\hline 4 & 3 & 6 & 7 & 8 & 1 & 5 & 2 & 9 \\
\hline
\end{array}
$$

The last bit of the above chromosome should be filled with the last number of vehicle. Considering the variable change, we have:

\begin{tabular}{|c|c|c|c|}
\hline Vehicle & \multicolumn{3}{|c|}{ Customer } \\
\hline 5 & 2 & 10 & 9 \\
\hline 1 & \multicolumn{3}{|c|}{-} \\
\hline 6 & 5 & 4 & 1 \\
\hline
\end{tabular}

According to the above chromosome, three customers are assigned to vehicles 5 and 6 and no customer is assigned to vehicle 1 . In fact, vehicle 1 is unused and not purchased.

The same process is repeated for other distribution centres. It is necessary to note that at any time period, customers without demand are eliminated from the final results.

To show how to assign suppliers to a producer, we use the same chromosome as customer and distribution centre chromosome.

Crossover operator: the parent chromosomes are broken from the break point and child chromosomes are created. The first half of the first child is taken from the first parent and the second half from the second parent. The second child is born from the parents' remaining genes. Duplicate genes in children chromosomes are identified and are swapped with each other.

For example, consider the following parents:

Assume the break point is 4. Parent chromosomes are broken as follows (Figure 4):

\begin{tabular}{l|l|l|l|l|l|l|l|l|}
\cline { 2 - 9 } Parent 1 & 2 & 5 & 4 & 1 & 3 & 6 & 8 & 7 \\
\hline Parent 2 & 6 & 8 & 4 & 1 & 7 & 3 & 5 & 2 \\
\cline { 3 - 10 } Child 1 & 2 & 5 & 4 & 1 & 7 & 3 & 5 & 2 \\
\hline Child 2 & 6 & 8 & 4 & 1 & 3 & 6 & 8 & 7 \\
\cline { 2 - 9 }
\end{tabular}

Figure 4 - Crossover operator

Preliminary chromosomes of children are generated as through crossover operator.

Feasibility step: Duplicate genes are identified in the above chromosomes shown in Figure 4. To justify the children, duplicate genes in children chromosomes are swapped with each other (Figure 5).

\begin{tabular}{l|l|l|l|l|l|l|l|l|}
\cline { 2 - 9 } Child 1 & 2 & 5 & 4 & 1 & 7 & 3 & 5 & 2 \\
\hline \multicolumn{1}{c|}{} \\
\hline \multirow{2}{*}{ Child 2 } & 6 & 8 & 4 & 1 & 3 & 6 & 8 & 7 \\
\cline { 2 - 9 }
\end{tabular}

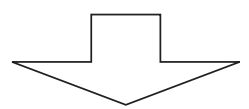

\begin{tabular}{l|l|l|l|l|l|l|l|l|}
\cline { 2 - 8 } Child 1 & 6 & 8 & 4 & 1 & 7 & 3 & 5 & 2 \\
\hline Child 2 & 2 & 5 & 4 & 1 & 3 & 6 & 8 & 7 \\
\cline { 2 - 9 } & &
\end{tabular}

Figure 5 - Feasibility

Mutation operator: To implement the mutation operator, first the number of genes' swaps is calculated using the user-defined rate. After calculating the number of swaps, the mutated chromosome is created as follows. Mutation operator is implemented as follows (Figure 6):

\begin{tabular}{|c|c|c|c|c|c|c|c|c|}
\hline $\begin{array}{c}\text { Initial } \\
\text { Chromosome }\end{array}$ & 8 & 4 & 1 & 7 & 3 & 5 & 6 & 2 \\
\hline Swap \#1 & 8 & 3 & 1 & 7 & 4 & 5 & 6 & 2 \\
\hline Swap \#2 & 8 & 3 & 1 & 6 & 4 & 5 & 7 & 2 \\
\hline $\begin{array}{c}\text { Mutated } \\
\text { Chromosome }\end{array}$ & 8 & 3 & 1 & 6 & 4 & 5 & 7 & 2 \\
\hline
\end{tabular}

Figure 6 - Mutation operator

In the proposed genetic algorithm, initial population will be produced randomly. Fitness function is defined as the total cost of every solution. Here the solution indicates a supply chain. Crossover and mutation operators are used in GA to produce new solutions in the neighbourhood. Among available solutions in a generation, the mutation operator selects one solution and mutates it to produce a new solution. The new generated solutions fitness will be evaluated through fitness evaluation function. If mutated solution has better fitness, it will be replaced with the old one. While implementing crossover in each generation, some solutions 
will be selected from the current population. Crossover operation will produce new solutions based on this set of selected ones. New solutions will be added to current generation. Finally the fittest solutions will be selected to make a new generation.

In genetic algorithm, the quality of each generation will be improved in every iteration. Crossover and mutation operators make new solutions. They will be added to the current population and the most fitted solutions will be selected to create the next generation.

\section{COMPUTATIONAL RESULTS}

\subsection{Random data set generation}

In order to validate the presented model, problems of different sizes (from small to large scale) should be generated and solved. The probability distributions to produce random sample problems are given in Table 1. The defined probability distributions are logically consistent with the model.

The parameters' range for their random generation is given in Table 1.

In Table 1, U([I u],\{a\}) represents a string with the length equal to the number of states of index a, and elements are random numbers uniformly distributed in [l u]. Parameters' dependencies have been considered in parameters intelligent simulation process to generate more validated problems.

\subsection{Solving small size problems via GAMS IDE/BONMIN}

For validation purpose, an algorithm was designed and coded in Matlab. Limits of parameters, given in
Table 2, are used in the algorithm for their random generation. It should be noted that algorithms, software and codes used in this research have been implemented on a system with the following specifications: Intel ${ }^{\circledR}$ Core (TM) 2 Dou CPU T9300 @2.5 GHz and RAM 3.00 GB. Eight small problems were generated and solved with GAMS. The results are reported in Table 2.

Results of solving eight small-size problems are provided in Table 2 using GAMS. It can be observed that the exact solution of the sample problems of small size is done in the interval 3.47 to 475.17 seconds with an average of 134.95 seconds. The objective function values (costs incurred from optimal decisions) are given in Table 2. The last column shows solving time of the defined problems. As problem size increases, solving time increases exponentially which reveals that the problem in this research is NP-hard

\subsection{GAMS IDE/BONMIN versus GA}

To show the efficiency of the presented genetic algorithm, here 15 problems of medium and large size are generated, in addition to 8 small problems previously defined. These problems have been solved with GAMS and GA. GAMS could solve 13 problems out of 23 and could not find a solution for large-scale problems. Figures 7 and 8 compare performance of genetic algorithm and exact method in problems in which the exact method has reached an optimal solution.

As problem size increases, the problem solving time increases exponentially. This shows the inherent complexity of these problems. It can be seen that there is insignificant gap between the optimal solution obtained by meta-heuristic algorithm and the exact solution in 13 problems, while there is significant

Table 1 - Parameters' range in random generation of sample problem

\begin{tabular}{|c|c|c|c|c|c|}
\hline$\#$ & Parameters & Distribution function & $\#$ & Parameters & Distribution function \\
\hline 1 & Node position $\mathrm{x}$ & $\mathrm{U}\left(\left[\begin{array}{l}0 \\
200],\{\mathrm{k}\})\end{array}\right.\right.$ & 15 & $D_{p k}$ & $N\left(\mu_{p k}, \sigma_{p k}\right)$ \\
\hline 2 & Node position y & $\mathrm{U}\left(\left[0 \mathrm{~L}^{200],\{\mathrm{k}\})}\right.\right.$ & 16 & $\mu_{p k}$ & $U\left[\begin{array}{lll}100 & 200]\end{array}\right.$ \\
\hline 3 & Node position x1 & $\mathrm{U}\left(\left[\begin{array}{ll}0 & 200],\{\mathrm{j}\}) \\
\end{array}\right.\right.$ & 17 & $\sigma_{p k}$ & $\mathrm{U}\left[\begin{array}{ll}10 & 15\end{array}\right]$ \\
\hline 4 & Node position y1 & $\mathrm{U}\left(\left[\begin{array}{ll}0 & 200],\{\mathrm{j}\}) \\
\end{array}\right.\right.$ & 18 & $A P_{p j}$ & $\mathrm{U}[20,00040,000]$ \\
\hline 5 & $F_{i}$ & $\mathrm{U}[300,000400,000]$ & 19 & $T_{p i}$ & U[200 500] \\
\hline 6 & $A M_{m i}$ & $\mathrm{U}[50,00080,000]$ & 20 & $b_{p}$ & U[300 700] \\
\hline 7 & $C M_{m i}$ & $U[100400]$ & 21 & $C V_{V}$ & $U[500,000700,000]$ \\
\hline 8 & $\max _{m i}$ & $\sum_{p, k, m, i} D_{p k} \cdot C O_{m i p} / I \cdot U\left[\begin{array}{ll}1 & 1.2\end{array}\right]$ & 22 & $\mathrm{CVeh}_{\mathrm{v}}$ & $\sum_{k, p} D_{p k} / V \cdot U\left[\begin{array}{ll}0.9 & 1.2\end{array}\right]$ \\
\hline 9 & $\min _{m i}$ & $\sum_{p, k, m, i} D_{p k} \cdot C O_{m i p} / I \cdot U\left[\begin{array}{ll}0.8 & 1\end{array}\right]$ & 23 & DCus $\hat{k} k$ & Euclidean distance $(\mathrm{x}, \mathrm{y})$ \\
\hline 10 & $\mathrm{CO}_{\text {mip }}$ & $\mathrm{U}[0.050 .5]$ & 24 & TCus $_{\text {vkkk }}$ & DCUS $\widehat{k} k \cdot u[0.81 .2] / 100$ \\
\hline 11 & $H M_{m}$ & $\mathrm{U}[500$ 1,000] & 25 & $D i s_{j k}$ & Euclidean distance $(\mathrm{x} 1, \mathrm{x}),(\mathrm{y} 1, \mathrm{y})$ \\
\hline 12 & $F_{W S}$ & $\mathrm{U}[1,000,0003,000,000])$ & 26 & $t m_{v j k}$ & $D i s_{j k \cdot U[0.81 .2] / 100}$ \\
\hline 13 & $C W_{j}$ & $\sum_{k, p} D_{p k} / J \cdot U\left[\begin{array}{ll}0.9 & 1.2\end{array}\right]$ & 27 & Fuel $_{v}$ & $\mathrm{U}[1 \mathrm{1} 2]$ \\
\hline 14 & $H P_{p}$ & $\mathrm{U}[6001,200]$ & 28 & CFuel & 1,000 \\
\hline
\end{tabular}


Nakhjirkan S, Mokhatab Rafiei F. An Integrated Multi-Echelon Supply Chain Network Design Considering Stochastic Demand...

Table 2 - Results of solving eight small-sized problems with GAMS

\begin{tabular}{|c|c|c|c|c|c|c|c|c|}
\hline \multirow{2}{*}{ Problem \# } & \multicolumn{6}{|c|}{ Indices } & \multirow{2}{*}{ Objective } & \multirow{2}{*}{$\begin{array}{c}\text { Runtime } \\
{[\mathrm{s}]}\end{array}$} \\
\hline & $\mathrm{I}$ & $\mathrm{J}$ & $\mathrm{K}$ & $\mathrm{P}$ & $\mathrm{M}$ & $\mathrm{V}$ & & \\
\hline S01 & 2 & 2 & 4 & 2 & 2 & 2 & $24,705,595$ & 3.476875 \\
\hline SO2 & 3 & 3 & 5 & 2 & 2 & 3 & $24,969,836$ & 4.841168 \\
\hline S03 & 3 & 4 & 6 & 3 & 2 & 3 & $26,358,913$ & 12.75722 \\
\hline S04 & 4 & 5 & 6 & 3 & 3 & 4 & $27,873,864$ & 31.33932 \\
\hline S05 & 4 & 6 & 7 & 4 & 3 & 4 & $43,075,295$ & 87.57199 \\
\hline S06 & 5 & 7 & 8 & 4 & 3 & 4 & $48,059,346$ & 179.2483 \\
\hline S07 & 5 & 7 & 9 & 5 & 3 & 5 & $61,903,935$ & 285.2098 \\
\hline S08 & 6 & 8 & 10 & 5 & 3 & 5 & $68,510,448$ & 475.1737 \\
\hline & & & & & & Min & $24,705,595$ & 3.476875 \\
\hline & & & & & & Mean & $40,682,154$ & 134.9523 \\
\hline & & & & & & Max & $68,510,448$ & 475.1737 \\
\hline
\end{tabular}

runtime reduction with genetic algorithm application. This shows that GA has had good performance. GAMS has not been able to solve big-size problems because of exponential growth of the size of solutions and system was out of memory before the pre-set time. As result, this process was stopped by GAMS IDE before reaching an acceptable local solution. But GA could find solutions for large-size problems.

Objective function Comparison

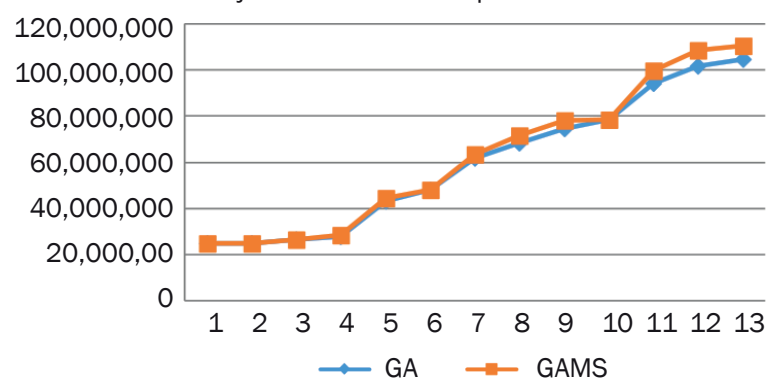

Figure 7 - Objective function changes in 13 problems (exact method and meta-heuristic genetic algorithm)

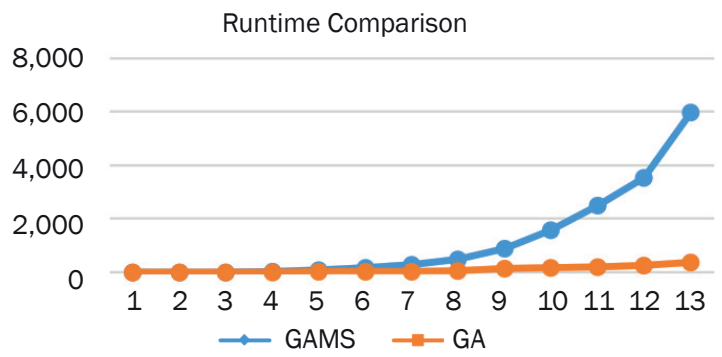

Figure 8 - Runtime changes in 13 problems (exact solution and meta-heuristic genetic algorithm)

\section{CONCLUSION}

In this article, a mixed integer non-linear programming model was presented to optimize a four-level supply chain including supply, production, distribution and demand levels in condition of demand uncertainty.
To design a supply chain with desirable performance, in addition to determining the optimal number of system parameters at the macro level, we took optimal policies at smaller levels particularly in the area of inventory control, routing and locating and designed an integrated supply chain with the proper functioning at the aforementioned four levels in interaction with each other.

Figure 9 shows how the transportation problem can be addressed through the proposed model. Imagine in a supply chain there are 5 potential places for distribution centres. The model implies that the optimum decision is establishing distribution centres 2 and 5 . As a result of solving the model, vehicles 3 and 4 will be utilized. Routing among distribution centres and customers is shown in Figure 9.

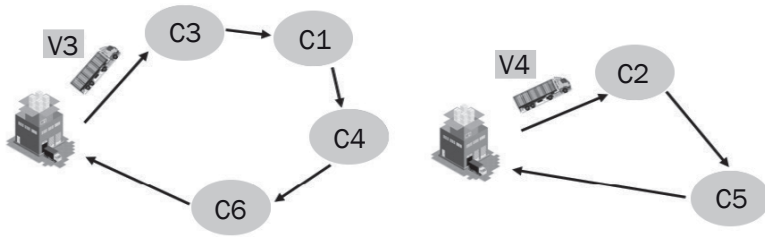

Figure 9 - Routing between distribution centres and customers

Optimization technique has been used to fulfil the objectives of the research. In the first step, a set of assumptions, goals and limitations of this problem were formulated in an integrated model. The final model had high complexity due to binary variables. Because we are faced with an NP-hard model, the complexity of the model limits the use of exact solution methods. To solve the proposed model and find an optimal solution, 13 problems of small and medium size were generated. The model was coded using GAMS for exact solution method and MATLAB for implementing the genetic algorithm. The sample problems solved using these two softwares and their optimal results 
were compared. It was observed that the meta-heuristic algorithm could solve small and medium problems and on the average more than $97 \%$ of efficiency was achieved in $15 \%$ of the exact solution time. So, the effectiveness of the proposed algorithm is proved based on 13 sample problems and it found quite accurate solutions with considerable solving time reduction. Solving time reduction is an important issue because real world problems have large dimensions and exact algorithms either might take too long to find an optimal solution for NP-hard models or even might not be able to solve them at all. Then, ten sample problems were designed at large scale that GAMS was incapable of solving and the suggested genetic algorithm achieved the possible answers in a reasonable time.

سارا نخجير كان

$$
\begin{aligned}
& \text { كارشناس ارشد مهندسى صنايع، دانشكده مهندسى صنايع و } \\
& \text { سيستمها، دانشخاه صنعتى اصفهان }
\end{aligned}
$$

\section{ايميل: nakhjirkan@yahoo.com}

$$
\text { دريماه مخاطب رفيعى }
$$

ايميل: f.mokhatab@modares.ac.ir

$$
\begin{aligned}
& \text { طراحى زنجيره تامين جندسطحى يكيار جه با تقاضاى } \\
& \text { تصادفى: رويكرد حل مبتنى بر العَوريتم زنتيك }
\end{aligned}
$$

جكيده

$$
\begin{aligned}
& \text { روند رو به رشد مصرف منابع طبيعى سبب ايجاد خسارتهاى } \\
& \text { جبران نايذيرى در محيط زيست شده است. دانشمندان بر اين }
\end{aligned}
$$

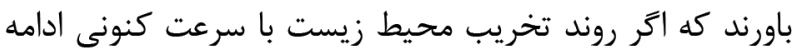

$$
\begin{aligned}
& \text { يابد، جشم انداز حيات بشر در هالهاى از ابهام قرار خواهد گرفت. } \\
& \text { يكى از موثرترين روشها براى مقابله با آثار مخرب زيست }
\end{aligned}
$$

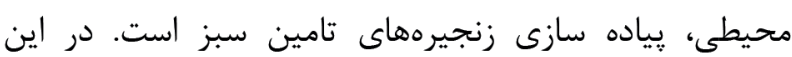

$$
\begin{aligned}
& \text { يزوهش يك مدل رياضى خندسطحى شامل سطوح تأمين، توليد، } \\
& \text { توزيع و مشترى براى مساله مسيريابى - مكانيابى - موجودى در } \\
& \text { زنجيره تامين سبز ارايه شده است. مسيريابى وسايط نقليه بين مين مئن } \\
& \text { سطوح توزيع و مشترى درنظر گرفته شده و محل احداث مراكز } \\
& \text { توزيع توسط مدل تعيين مى } \\
& \text { سياست بازنگرى (r,Q) به منظور كنترل موجودى بهره }
\end{aligned}
$$

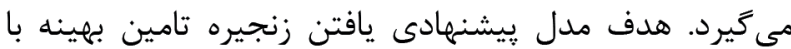

$$
\begin{aligned}
& \text { كمترين هزينه است. به منظور اعتبارسنجى مدل ييشنهرادى و }
\end{aligned}
$$

سنجش ميزان انطباق آن با مفاهيهم و واقعيت بيرونى مساله از

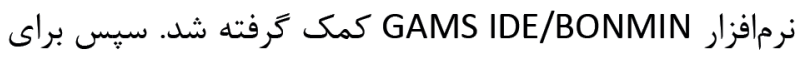
سنجش كارايى مدل در ابعاد بزرگ از الخُوريتم زنتيك استفاده شده است. نتايج حاصله مويد كارآيى مدل ريشنههادى به عنوان يك ابزار كاربردى براى تصميمَيران در حل مساله مسيريابى - مابع

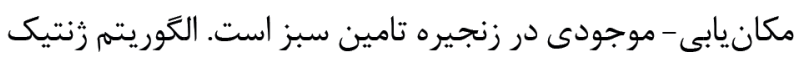

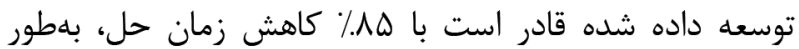
متوسط 9V\% به جواب بهينه نزديك شود.

كلمات كليدى: شبكه زنجيره تامين، برنامهريزى رياضى تصادفى، مكانيابى -موجودى-مسيريابى، الخوريتم زنتيك ريكي

\section{REFERENCES}

[1] Prodhon C. Le problème de localisation-routage [PhD Thesis]. France: University of Technology of Troyes; 2006.

[2] Gebennini E, Gamberini R, Manzini R. An integrated production-distribution model for the dynamic location and allocation problem with safety stock optimization. International Journal of Production Economics. 2009;122(1):286-304. doi: 10.1016/ j.ijpe.2009.06.027

[3] Prins C, Prodhon C, Ruiz A. Soriano P. Wolfler-Calvo R. Solving the capacitated location-routing problem by a cooperative Lagrangean relaxation granular tabu search heuristic. Transportation Science. 2007;41(4):470-83. doi: 10.1287/trsc.1060.0187

[4] Belenguer JM, Benavent E, Prins C, Prodhon C, Wofler-Calvo R. A branch-and-cut method for the capacitated location-routing problem. Computers \& Operations Research. 2011;38(6):931-41. doi: 10.1016/ j.cor.2010.09.019

[5] Prodhon C. A hybrid evolutionary algorithm for the periodic location-routing problem. European Journal of Operational Research. 2011;210(2):204-12. doi: 10.1016/j.ejor.2010.09.021

[6] Nagy G, Salhi S. Location-routing issues models and methods: A review. European Journal of Operational Research. 2007;117:649-72. doi: 10.1016/ j.ejor.2006.04.004

[7] Prodhon C, Prins C. A survey of recent research on location-routing problems. European Journal of Operational Research. 2014;238:1-17. doi: 10.1016/ j.ejor.2014.01.005

[8] Bertazzi L, Paletta G, Speranza M. Deterministic order-up-to level policies in an inventory routing problem. Transportation Science. 2002;36(1):119-32. doi: 10.1287/trsc.36.1.119.573

[9] Cha BC, Moon IK, Park JH. The joint replenishment and delivery scheduling of the one-warehouse n-retailer system. Transportation Research Part E Logist. Transp. Rev. 2008;44(5):720-30.

[10] Solyali O, Cordeu JF, Laporte G. Robust inventory routing under demand uncertainty. Transportation Science. 2010;46(3):327-40. doi: 10.2307/23263546

[11] Oppen J, Lokketangen A, Desrosiers J. Solving a rich vehicle routing and inventory problem using column generation. Computers and Operations Research. 2010;37:1308-317. doi: 10.1016/j.cor.2009.09.014 
[12] Kleywegt A, Nori VS, Savelsbergh MWP. The stochastic inventory routing problem with direct deliveries. Transportation Science. 2002;36:94-118. doi: 10.1287/ trsc.36.1.94.574

[13] Vidovic M, Popovic D, Ratkovic B. Mixed integer and heuristics model or the inventory routing problem in fuel delivery. Int. J. Production Economics. 2014;147:593604. doi: 10.1016/j.ijpe.2013.04.034

[14] Andersson H, Hoff A, Christiansen M, Hasle G, Løkketangen $A$. Invited review: industrial aspects and literature survey: combined inventory management and routing. Computers \& Operations Research. 2010;37:1515536. doi: 10.1016/j.cor.2009.11.009

[15] Daskin M, Coullard C, Shen ZJ. An inventory location model: formulation, solution algorithm and computational results. Annals of Operations Research. 2002;110:83-106. doi: 10.1023/A:1020763400324

[16] Shen ZJ. A multi commodity supply chain design problem. IIE Transactions. 2005;37:753-62. doi: $10.1080 / 07408170590961120$

[17] Ma H, Davidrajuh R. An iterative approach for distribution chain design in agile virtual environment. Ind. Manage. Data System. 2005;105(6):815-34. doi: 10.1108/02635570510607012

[18] Miranda P, Garrido R. Inventory service-level optimization within distribution network design problem. International Journal of Production Economics. 2009;122(1):276-85. doi: 10.1016/ j.ijpe.2009.06.010

[19] Liu SC, Lee SB. A two-phase heuristic method for the multi-depot location routing problem taking inventory control decisions into consideration. The International Journal of Advanced Manufacturing Technology. 2003;22:941-50. doi: 10.1007/s00170-003-1639-5

[20] Ambrosino D, Scutellà MG. Distribution network design: new problems and related models. European Journal of Operational Research. 2005;165(3):610-624. doi: 10.1016/j.ejor.2003.04.009

[21] Guerrero WJ, Prodhon C, Velasco N, Amaya CA. Hybrid heuristic fortheinventorylocation-routingproblem with deterministic demand. Int. J. Prod. Econ. 2013;146(1):359-70. doi: 10.1016/ j.ijpe.2013.07.025

[22] Ahmadi Javid A, Azad N. Incorporating location, routing and inventory decisions in supply chain network design. Transportation Research Part E: Logistics and Transportation Review. 2010;46(5):582-97. doi: 10.1016/j. tre.2009.06.005

[23] Hiassat A, Diabat A. Location-inventory-routing-problem with perishable products. Paper presented at: 41st International Conference on Computers and Industrial Engineering; 2011 October 23-25; Los Angeles, California, USA.

[24] Lerhlaly S, Lebbar M, Allaoui H, Ouazar D, Afifi S. An Integrated Inventory Location Routing Problem Considering CO2 Emissions. Contemporary Engineering Sciences. 2016;9(7):303-314. doi: 10.12988/ces.2016.512326

[25] Gutiérrez MG, Silva CW. Inventory Location Routing Problem: A Column Generation Approach. Paoer presented at: International Conference on Industrial Engineering and Operations Management; 2012 July 3-6; Istanbul, Turkey.

[26] Zhang Y, Qi M, Miao L, Liu E. Hybrid metaheuristic solutions to inventory location routing problem. Transportation Research Part E. 2014;70:305-23. doi: 10.1016/j. tre.2014.07.010

[27] Bae ST, Hwang HS, Cho GS. Goan MJ. Integrated GA-
VRP solver for multi-depot system. Computers \& Industrial Engineering. 2007;53(2):233-40. doi: 10.1016/ j.cic.2007.06.014

[28] [28] Oliveira FB, Enayatifar R, Sadaei HJ. Guimarães FG. Potvin, JY. A cooperative coevolutionary algorithm for the multi-depot vehicle routing problem. Expert Systems with Applications. 2016;43(1):117-30. doi: 10.1016/j.eswa.2015.08.030

[29] Mirabi M, Ghomi SF, Jolai F. Efficient stochastic hybrid heuristics for the multi-depot vehicle routing problem. Robotics and Computer-Integrated Manufacturing. 2010;26(6):564-69. doi: 10.1016/ j.rcim.2010.06.023

[30] Kuo Y. Using simulated annealing to minimize fuel consumption for the time-dependent vehicle routing problem. Computers \& Industrial Engineering. 2010;59(1):157-65. doi: 10.1016/j.cie.2010.03.012

[31] US Department of Energy. Fuel Economy Guide; 2008. Available from: http://www.fueleconomy.gov

[32] Ebrahimi Qazvini Z, Amalnick S, Mina H. A green multi-depot location routing model with split-delivery and time window. Int. J. Management Concepts and Philosophy. 2016;9(4):271-282. doi: 10.1504/ IJMCP.2016.079837

[33] Ćirović G, Pamučar D, Božanić D. Green logistic vehicle routing problem: routing light delivery vehicles in urban areas using a neuro-fuzzy model. Expert Systems with Applications. 2014;41(9):4245-58. doi: 10.1016/ j.eswa.2014.01.005

[34] Qian J, Eglese R. Fuel emissions optimization in vehicle routing problems with time varying speeds. European Journal of Operational Research. 2016;248(3):840-48. doi: 10.1016/j.ejor.2015.09.009

[35] Felipe Á, Ortuño MT, Righini G, Tirado G. A heuristic approach for the green vehicle routing problem with multiple technologies and partial recharges. Transportation Research Part E: Logistics and Transportation Review. 2014;71(1):111-28. doi: 10.1016/ j.tre.2014.09.003

[36] Kramer R, Maculan N, Subramanian A, Vidal T. A speed and departure time optimization algorithm for the pollution-routing problem. European Journal of Operational Research. 2015;247(3):782-87. doi: 10.1016/ j.ejor.2015.06.037

[37] Koç Ç, Karaoglan I. The green vehicle routing problem: a heuristic based exact solution approach. Applied Soft Computing. 2016;39(1):154-64. doi: 10.1016/ j.asoc.2015.10.064

[38] Ramezanzadeh BR, Kianfar F. A fuzzy mathematical model for supplier selection and order allocation considering green vehicle routing problem. Int. J. Logistics Systems and Management. 2017;27(2):151-163. doi: 10.1504/IJLSM.2017.083811

[39] Beamon MB. Measuring supply chain performance. International Journal of Operations \& Production Management. 1999;19(3):275-92. doi: 10.1108/01443579910249714

[40] Guan R, Zhao X. On contracts for VMI program with continuous review $(r, Q)$ policy. European Journal of Operational Research. 2010;207(2):656-67. doi: 10.1016/ j.ejor.2010.04.037 